\title{
Institutional linkages and landscape governance systems: the case of Mt. Marsabit, Kenya
}

\author{
Lance W. Robinson ${ }^{1}$ and Joram K. Kagombe ${ }^{2,3}$
}

\begin{abstract}
The desire to overcome fragmented management of the natural ecosystems on which human beings depend has contributed to a growing interest in landscape approaches and to deeper questions about landscape governance systems. We assessed the emergent governance system that corresponds to the Mt. Marsabit landscape ecosystem in northern Kenya, applying a framework that includes 17 different indicators. We found that in this governance system, the most important spaces where coordination and joint planning took place were district level coordination committees, within which representation of communities and voices from the grassroots was poor. Institutional and organizational linkages were such that those parts of the governance system for which legitimacy and accountability were strongest were the parts for which ability to generate resources was weakest, while the parts of the governance system that had the best access to resources was where accountability was weakest or the most indirect. In this paper we use the Mt. Marsabit case study to explore the role that organizational and institutional linkages play in the strengths and weaknesses of landscape governance systems, and consider the implications for governance design at landscape level. Institutional linkages play a critical role in determining how landscape governance systems function across scales and levels, and their degree of fit. Appropriate linkages can help to create connections among key dimensions of effective governance within the system, dimensions such as use of knowledge, capacity to generate resources, fit, learning, legitimacy, accountability, and responsiveness, strengthening the system as a whole. Of the various linkages that characterize a governance system, it is those that give community-level actors a meaningful voice at higher levels and in spaces where key decisions are being made that are most critical for enabling effective landscape governance.
\end{abstract}

Key Words: environmental governance; governance systems; institutional linkages; landscape governance; Mt. Marsabit

\section{INTRODUCTION}

The desire to overcome fragmented management and to care for the natural systems on which human beings depend has driven interest in strategies such as ecoregional conservation planning (Powell 2010), ecosystem-based management (Slocombe 1998), and landscape approaches (Sayer et al. 2013). Within these overlapping areas of practice and scholarship, an initial focus on strategies and management approaches is now increasingly accompanied by an interest in deeper questions around structures and processes of governance (e.g., Kozar et al. 2014, Minang et al. 2015a). The furthest reaching variants of this kind of thinking, such as bioregionalism, hold that political interests and boundaries should be realigned to correspond to natural systems (Sale 2000). Although ecosystem-based management and landscape approaches tend to be less ambitious than this, they do aim at creating structures and processes for information sharing, planning, and monitoring that can overcome fragmented decision making and the problem of spatial misfit (Galaz et al. 2008) between institutions and the nature of the social-ecological systems they are meant to govern.

However, the problem of misfit relates not only to the relationship between biophysical systems and particular institutions, but also to lack of "fit" between biophysical systems and governance systems (Galaz et al. 2008). The interest to look beyond the role and function of single institutions to consider broader "governance architectures" or "governance systems" can be seen in recent literature on environmental governance across the spectrum from scholarship on local commons to the study of earth system governance (e.g., Andersson and Ostrom 2008, Biermann 2008, Galaz et al. 2008). A governance system can be understood as comprising an assortment of institutions and organizations, as well as features such as networks, policies, principles, and practices (Biermann et al. 2009, Duit et al. 2010). It is also important to note that governance systems function across scales and levels. Local level commons, it has been noted (Berkes 2009), are embedded in a multilevel world. And while there are elements of consciously designed relationships among some components of governance systems, many of the relationships, dynamics and ultimate behavior of governance systems are unplanned and emergent. Governance systems, in other words, can be understood as complex, multilevel systems amenable to the kinds of analyses used for studying complex ecological and social-ecological systems (Jentoft et al. 2007, PahlWostl 2009, Lockwood 2010, Young 2010).

Although it is recognized that institutional linkages play an important role in environmental management and governance, more work is needed to unpack and better understand how institutional linkages help to determine the nature and performance of governance systems including in the context of landscape governance. In this paper, we do this through an assessment of the governance system that corresponds to the Mt. Marsabit landscape ecosystem in northern Kenya. The stark physical difference between Mt. Marsabit and the arid lowlands that surround it, and the nature of the ecological and social relationships that characterize its natural resources and determine how they are managed and used, justify treating Mt. Marsabit as a landscape ecosystem for purposes of this assessment. There is, however, no jurisdiction that neatly corresponds to Mt. Marsabit. The governance system that corresponds to it is made up of a variety of organizations and institutions operating at various scales and levels, and the linkages among them. Although many of the components of the system are consciously designed, the 
system as a whole is not. With our assessment of this governance system, we explore the role that institutional linkages play in the strengths and weaknesses of this emergent system, and consider the implications for governance design at landscape level.

\section{LINKAGES, GOVERNANCE, LANDSCAPES}

The nature of governance systems, their functioning, and effectiveness depend upon the interplay of institutions, organizations, and networks including across scales and levels (Kofinas 2009). In recent years, the study of environmental governance has increasingly directed attention to institutional linkages, understood here to refer to connections and interactions between and among both organizations and institutions (Robinson and Berkes 2011). The attention to linkages can be seen in commons scholarship, for instance: whereas this body of work initially tended to emphasize the form particular institutions would take, eventually institutional linkages across scales and levels and institutional dynamics became a focus of study (Berkes 2002). Institutional linkages, both vertically across levels and horizontally within the same level, have been identified as critical factors in environmental governance systems (Cash et al. 2006, Lebel et al. 2006, Gehring and Oberthür 2008). The effects of institutional linkages are several. Governance systems that are well connected tend to have greater levels of mutual respect and trust (Lockwood 2010). Institutional linkages are also important for adaptive capacity in that adaptive capacity can perhaps best be understood not as a property of particular actors within a system but as a property of the system as a whole, based particularly on the network of institutional linkages that characterizes that system (Robinson and Berkes 2011).

Landscape approaches can be understood as an attempt to overcome the lack of a multilevel approach and paucity of linkages across sectors and jurisdictions. Management of landscapes and ecosystems is complex and difficult to understand and to implement, and therefore is not conducive to central control (Folke et al. 2005). Instead, an adaptive approach is needed, which in turn requires linkages across scales and levels (Folke et al. 2005, Cash et al. 2006, Lebel et al. 2006). It is increasingly recognized that success for landscape approaches depends on governance systems that are nested across levels (Kozar et al. 2014, Duguma et al. 2015, Minang et al. 2015b). Landscape approaches can be thought of as the nesting of community-based natural resource management (Brunckhorst 2010). Aside from the importance of addressing challenges across scales and levels, there is a need for integration of social, economic, and environmental objectives and for integration across sectors, tasks for which conventional governance systems are ill-equipped (Mbow et al. 2015). These challenges and the role of institutional linkages in overcoming them are central to ecosystem-based management, landscape approaches, and related strategies. Indeed, ecosystem-based management has been described as an attempt "to develop an institutional ecosystem" (Imperial 1999:452).

However, precisely how institutional linkages affect the functioning of governance systems and what practically this may mean for the design of landscape governance is less clear. When the recognition of the importance of multiple scales, levels, and jurisdictions, and connections across scales, levels, and jurisdictions is combined with a recognition of the political dimension, it becomes clear that landscape governance is "messy" (Kozar et al. 2014). One of the ways in which institutional linkages affect governance systems is by creating networks that facilitate the sharing of knowledge, and joint learning and problem-solving (Carlsson and Berkes 2005, Wyborn 2015). Another effect of linkages is through the role they play structuring participation in decision making. They can provide avenues for input from lower levels, including input from individual citizens, into decisions made at higher levels. It has been suggested (Robinson and Berkes 2011) that there are three key elements of meaningful multilevel participation: an institutional environment in which the various levels of institutions are linked, inclusivity in decision making at these various levels, and deliberation. By connecting organizations and institutions at lower levels to governance mechanisms at higher levels, institutional linkages may also help to legitimize the former in the eyes of citizens. Exploration of the relationships between institutional linkages and dimensions of governance such as deliberation, equity and inclusivity, accountability, learning, and the resolution of trade-offs can be expected to yield important insights for the design of governance systems that better "fit" social-ecological landscapes and ultimately provide better governance.

\section{ANALYTICAL FRAMEWORK}

The basis of analysis was the Framework for Assessing Governance for Landscape-Level Ecosystem-Based Management (Robinson et al. 2012a). In the assessment framework, governance systems are assessed according to various dimensions and indicators. There are eight descriptive questions and 17 evaluative indicators, representing various dimensions of governance. The framework draws particularly on the work of Gupta et al. (2010), but with several adaptations to make it more appropriate for assessment of governance systems rather than single institutions. The evaluative indicators are grouped into governance processes, governance capacities, and governance outcomes. This grouping is not intended to represent a theory of causality in governance, but rather is meant as a heuristic to aid in asking questions about causality (see Table 1). Below we describe each of the indicators, identifying where we have followed Gupta et al. (2010) closely and referring to other literature where we do not.

There are eight indicators of governance processes. Indicator no. $\mathrm{I}-1$, asks to what extent there is deliberation among stakeholders and decision makers on important issues. Deliberation is important because without it participation proceeds as if interests, positions, and knowledge are fixed (Miller 1992, Smith et al. 2001, Smith 2003), functioning only as inputs to decision making with no possibility for mutual learning. Deliberation is a key element of meaningful multilevel participation, contributing to effective feedback and decision-making mechanisms, enabling the coproduction of knowledge, and contributing ultimately to empowerment (Robinson and Berkes 2011). The second indicator assesses the ability of the system to generate resources. Following Gupta and coauthors (2010), we group resources into three types: financial resources, human resources, and political resources. Indicator I-3 asks whether there are appropriate linkages among organizations and institutions, especially across levels. Interplay and linkages among organizations and institutions, both vertically across levels and horizontally within the same level, have been identified as critical factors in resilient social-ecological systems (Gunderson et al. 2006) and environmental governance 
Ecology and Society 23(1): 27

https://www.ecologyandsociety.org/vol23/iss1/art27/

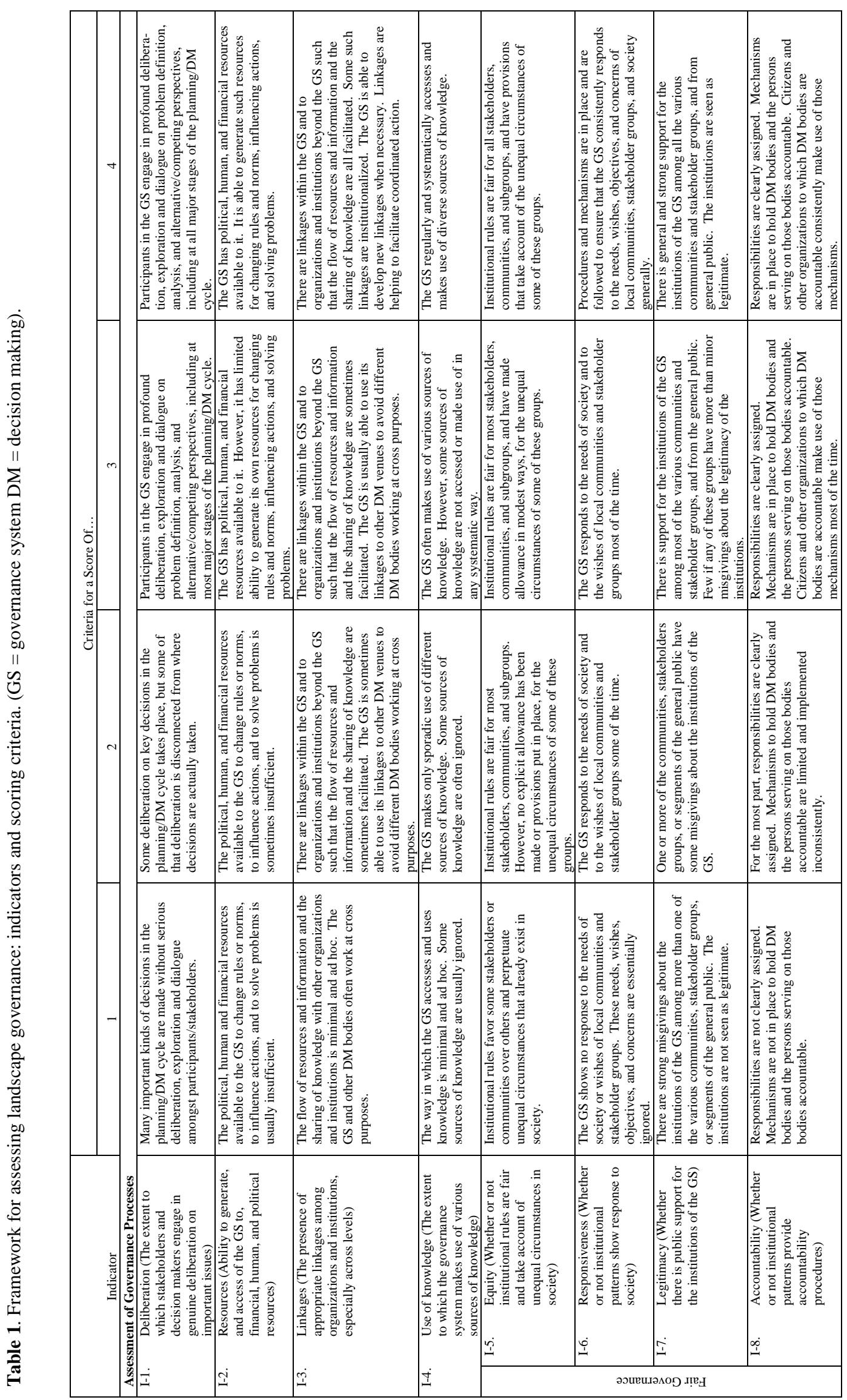




\begin{tabular}{|c|c|c|c|c|c|c|c|c|c|}
\hline & 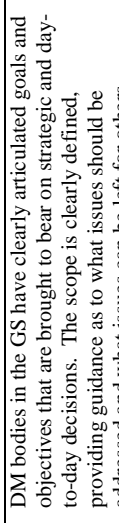 & 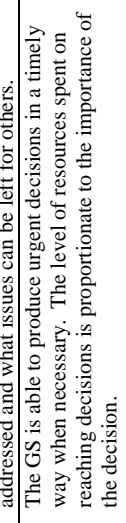 & 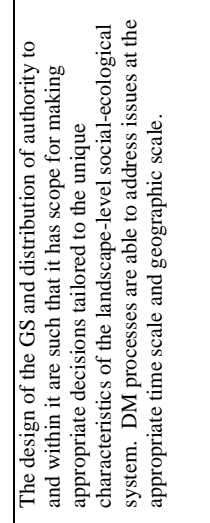 & 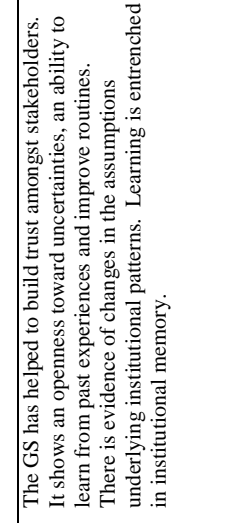 & 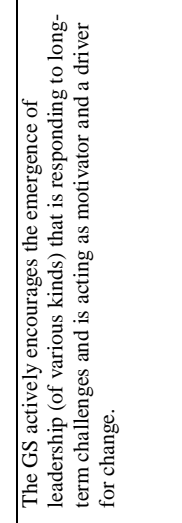 & 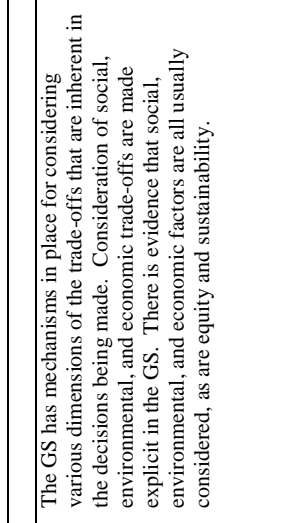 & 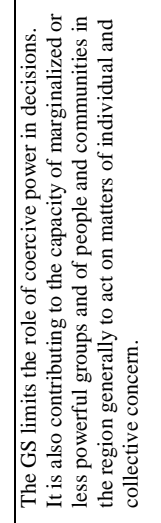 & 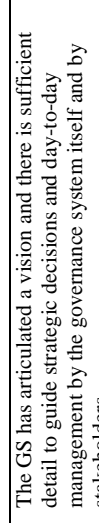 & 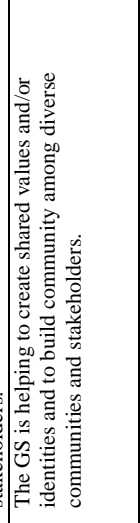 \\
\hline & 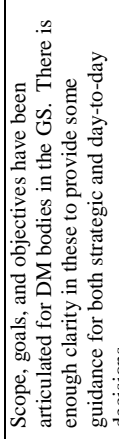 & 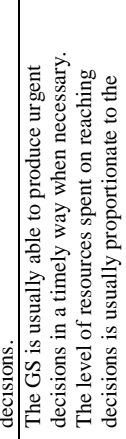 & 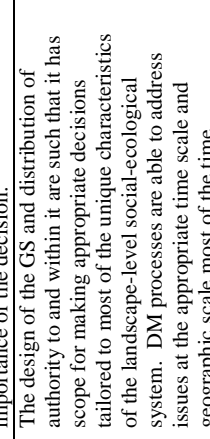 & 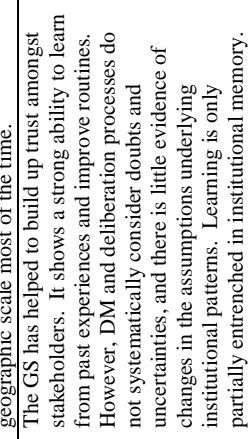 & 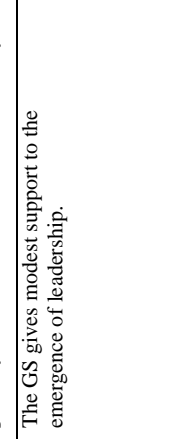 & 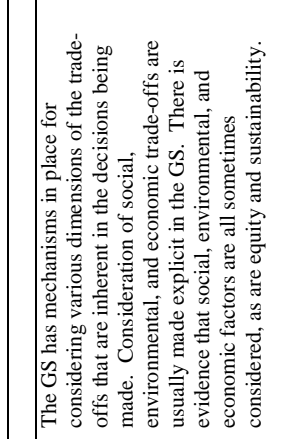 & 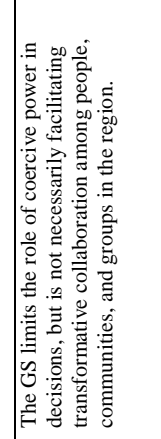 & 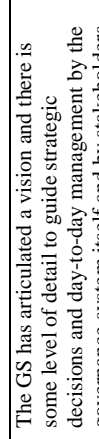 & 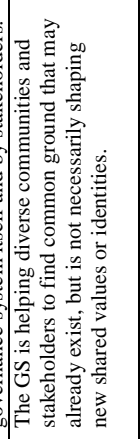 \\
\hline & 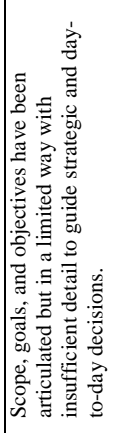 & 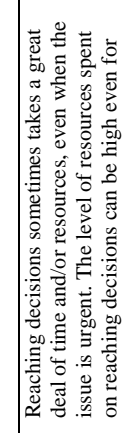 & 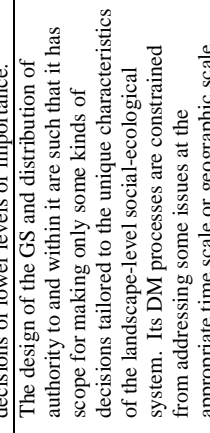 & 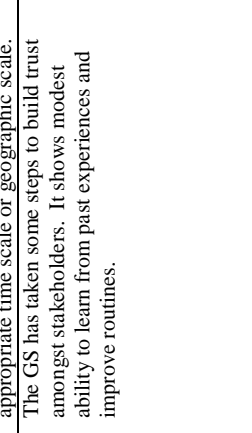 & 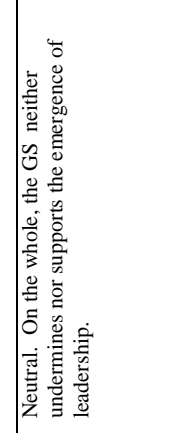 & 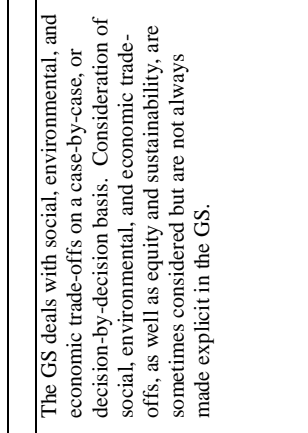 & 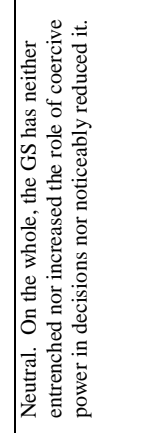 & 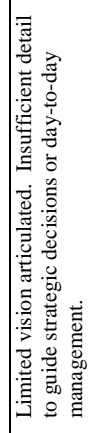 & 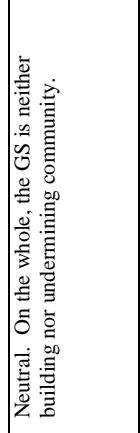 \\
\hline & 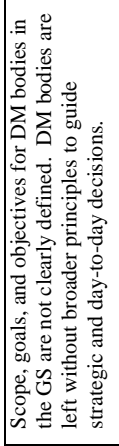 & 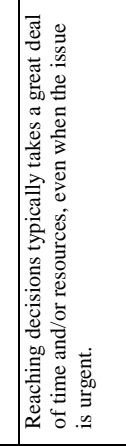 & 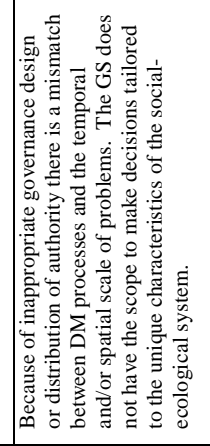 & 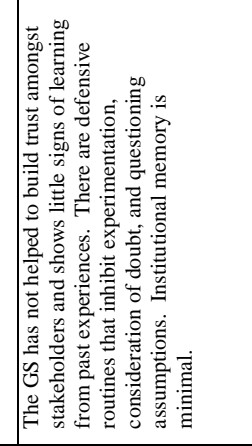 & 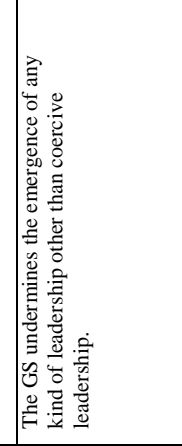 & 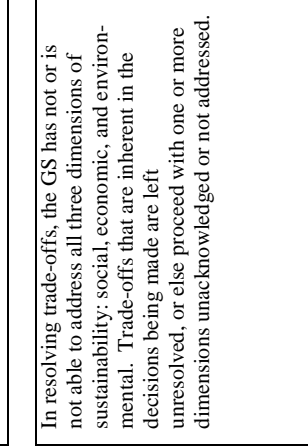 & 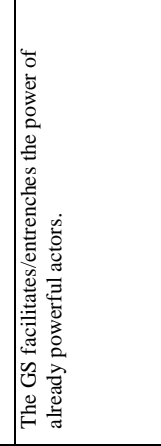 & 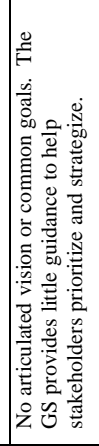 & 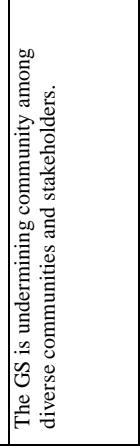 \\
\hline & 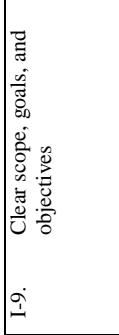 & 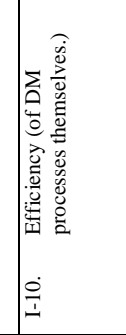 & 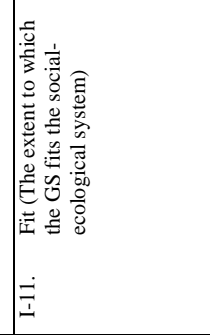 & 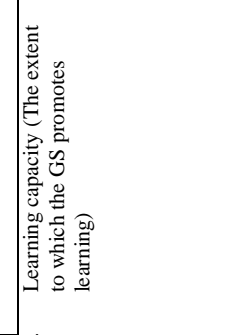 & 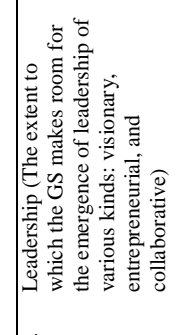 & 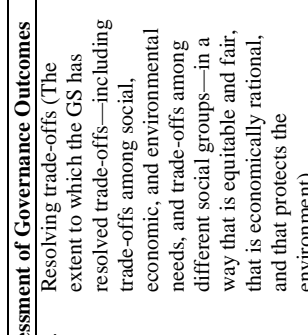 & 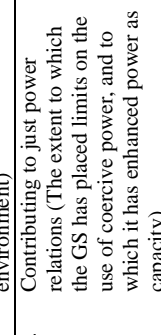 & 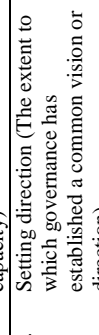 & 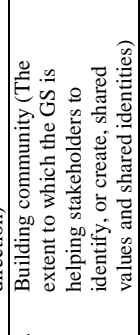 \\
\hline 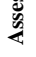 & & s̈uуye & HA & it & $\stackrel{\stackrel{m}{I}}{\dot{I}}$ & $\stackrel{ \pm}{I}$ & 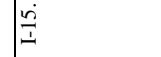 & & 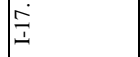 \\
\hline
\end{tabular}


systems (Cash et al. 2006, Lebel et al. 2006, Gehring and Ruffing 2008), particularly in the capacity of such systems to adapt to change (Robinson and Berkes 2011). The fourth indicator asks to what extent the governance system makes use of various sources of knowledge. Being able to draw on different sources and types of knowledge is important for the capacity to assess complex problems and find innovative solutions (Berkes and Folke 2002, Folke et al. 2005).

There is also a set of governance process indicators that can be grouped together under the heading of fair governance. Gupta and coauthors (2010) identify four dimensions here: equity, legitimacy, responsiveness, and accountability. For all of these indicators we are referring to the governance processes rather than to the outcomes or actual decisions. Although the fairness of governance processes on the one hand, and of societal outcomes on the other, are obviously connected, we separate them because we hypothesize that it is possible to have governance processes that are equitable, legitimate, responsive, and accountable, but which nevertheless sometimes make decisions and produce outcomes that are not fair.

There are five indicators that we group under governance capacities. Three of them relate to effective decision making and here we distinguish the effectiveness of the decision-making process from assessing the ultimate overall effectiveness of the governance system at producing desirable outcomes. Effective decision making presupposes the existence of clear goals and objectives (Graham et al. 2003); Indicator I-9, therefore, is concerned with the extent to which these are in place for the governance system. Efficiency is also important: stakeholders have only so much time and organizations have finite resources, so the need for careful review, use of research and other knowledge, and dialogue must be balanced against the efficiency of the process. Effective decision making also depends on how well the governance system matches the social-ecological system for which decisions are being made. Some authors (e.g., Young 2002, Galaz et al. 2008) refer to this as the quality of fit. For the two other indicators that are part of governance capacities we draw on Gupta and coauthors (2010): the extent to which the governance system promotes learning (I-12), and the extent to which it makes room for the emergence of leadership of various kinds (I-13).

Last, the indicators that we refer to as indicators of governance outcomes are based on the notion of governance being a set of social functions. Whereas government is a set of organizations, governance is a social function (Young 1996) or, according to some, a set of social functions: namely, the resolution of tradeoffs, the shaping of the use of power, setting direction, and building community (Robinson et al. 2012b, Robinson and Makupa 2015). The first of these is sometimes referred to as "social coordination" (Olsson 2007) or "value integration" (Lockwood 2005). Indicator I-14, therefore, is concerned with the extent to which the governance system has been able to integrate values and resolve trade-offs, including trade-offs among social, economic, and environmental needs, and trade-offs among different social groups. Indicator I-15 is concerned with the way and extent to which the governance system shapes and curbs how power is used. We are concerned here with both coercive power (what is sometimes called "power over"), and power as capacity (sometimes called "power to" and "power with"; Rowlands 1997). Whereas the fair governance indicators (I-5 to I-8) relate to ways in which the collective decision making and representation processes are equitable, responsive, legitimate, and accountableall of which will certainly be influenced by the nature of power relations - this indicator is concerned with outcomes of governance on power relations. The next indicator relates to the function of setting direction, which other authors refer to as "revisioning" (Waltner-Toews and Kay 2005) or "steering" (Young 2008). The fourth social function and our 17th indicator relates to the role played by governance in shaping values and building community (Robinson and Makupa 2015).

\section{METHODS}

Field research was conducted from January to August 2013. Data collection included 18 semistructured interviews with 23 key informants (some interviews were conducted with two respondents together; see Appendix 1), one focus group with pastoralist elders, and one workshop with a mix of stakeholders represented. Approximately half of the interviews were conducted in English. The remaining interviews and the focus group discussion and workshop were conducted in local languages, Rendille and Borana, with the help of a research assistant/translator from the area. Participants in the research were selected with the help of local informants to represent a diversity of possible viewpoints, in particular taking care to ensure that different stakeholder groups and types of organizations, and both women and men, were represented. All of them were involved in decision making and management of natural resources on Mt. Marsabit and therefore were knowledgeable about at least some aspects of governance and key institutions in the governance system.

Each of 17 indicators was assessed according to a set of scoring criteria with a score of " 1 " being weakest and " 4 " strongest. Use of specific criteria pertaining to each score helped to make the scoring more robust than an approach that merely rates each criterion with labels such as "very strong," "strong," "weak" etc. (see Table 1). The authors assessed the information gathered to see for each indicator which of the four criteria mostly closely described Mt. Marsabit governance system. Initial judgments based on review of documentation, interviews, and the focus group discussion were discussed at the workshop to allow for further triangulation. Justifications for the scores assigned are summarized in the right-most column in Tables 2 and 3. It must be noted, however, that in applying the framework, qualitative findings associated with each indicator received more attention than the scores. Although institutional linkages is itself only one of the 17 indicators, our analysis of the Mt. Marsabit case in this paper focuses on linkages and their role in the overall functioning and performance of the governance system.

As tentative conclusions were formulated, attempts were made through further interactions with participants to find disconfirming opinions and evidence. The interviews and focus group were transcribed and the workshop summarized, and then the resulting transcripts analyzed using the qualitative analysis software NVivo. Respondents' statements from interviews, the focus group, and the workshop were coded by one of the researchers according to their relevance to the 17 indicators described above. New themes were also identified during the 
Table 2. Assessment of governance processes and capacities. $($ EMCs $=$ environmental management committees; KFS = Kenya Forest Service; KWS = Kenya Wildlife Service; DEC = District Environment Committee).

\begin{tabular}{|c|c|c|c|c|}
\hline Task & \multicolumn{2}{|c|}{ Questions/Indicators } & Score & Explanation \\
\hline \multirow{8}{*}{ 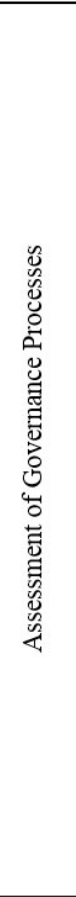 } & $\mathrm{I}-1$ & Deliberation & 2 & $\begin{array}{l}\text { Deliberation did happen but was sporadic. Technical coordination forums often focused on sharing of } \\
\text { information rather than analysis and dialogue. One of the main venues for deliberation has been workshops } \\
\text { and other forums organized for the planning or launching of a new project, but this kind of deliberation is not } \\
\text { institutionalized into regular decision-making processes. }\end{array}$ \\
\hline & I-2. & Resources & 1 & $\begin{array}{l}\text { Ability to generate financial resources has been poor. Human resources were insufficient, especially for } \\
\text { enforcement. The capacity of EMCs has partly compensated for this, but they too have been poorly resourced. } \\
\text { Overall the ability of the governance system to generate resources for key governance activities such as } \\
\text { coordination and planning was usually insufficient. }\end{array}$ \\
\hline & I-3. & Institutional linkages & 3 & $\begin{array}{l}\text { Strong linkages existed for coordination and sharing of information among government actors and NGOs. } \\
\text { There was little in the way of different actors working at cross purposes. However, connections to community } \\
\text { actors such as EMCs and to elected representatives, especially ward councilors, were weak. }\end{array}$ \\
\hline & I-4. & Use of knowledge & 2 & $\begin{array}{l}\text { The governance system made only sporadic use of different sources of knowledge. Some sources of } \\
\text { knowledge, e.g., traditional knowledge and scientific research, were often ignored. }\end{array}$ \\
\hline & & I-5. Equity & 2 & $\begin{array}{l}\text { Although institutional rules are generally fair, the governance system had little provision to ensure that the } \\
\text { poorest and most vulnerable segments of the population had representation and voice in collective decision } \\
\text { making. }\end{array}$ \\
\hline & 苂 & I-6. Responsiveness & 2.5 & $\begin{array}{l}\text { There were several signs of responsiveness to the needs and wishes of various groups in the communities. } \\
\text { Responsiveness was weakened by the fact that key elements of coordination, information sharing, and } \\
\text { collaborative decision making take place in technical forums where community actors have not been well } \\
\text { represented. Also responsiveness to the needs of the poorest and most vulnerable groups was weak. }\end{array}$ \\
\hline & 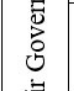 & I-7. Legitimacy & 2 & $\begin{array}{l}\text { The legitimacy of the overall governance system was mixed. The roles KFS and KWS are acknowledged } \\
\text { although often in a begrudging way. Legitimacy was strongest for traditional institutions and EMCs. } \\
\text { However, these were not the central players in the governance system. }\end{array}$ \\
\hline & I & I-8. Accountability & 2.5 & $\begin{array}{l}\text { In the governance system, accountability was strongest for EMCs and elected representatives (ward } \\
\text { councilors). Elsewhere, it was weaker, more indirect, or both. Across the whole governance system, parts of } \\
\text { the system that had the best access to resources had the lowest level of accountability and parts that had the } \\
\text { worst access to resources had the strongest level of accountability. Although there were channels and } \\
\text { mechanisms of accountability, for parts of the governance system these channels and mechanisms could not be } \\
\text { easily accessed by community members. }\end{array}$ \\
\hline 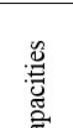 & 兽 & $\begin{array}{l}\text { I-9. Clear scope, } \\
\text { goals, and } \\
\text { objectives }\end{array}$ & 2 & $\begin{array}{l}\text { Coordination bodies such as the DSG and DEC had relatively clear guidance themselves, and they helped with } \\
\text { information sharing and guidance to government departments. However, for the governance system as a } \\
\text { whole, more work needs to be done. For instance, there is not a forest management plan or other resource } \\
\text { management plan guiding all stakeholders around the mountain. }\end{array}$ \\
\hline$\bigcup_{\tilde{U}}^{\tilde{U}}$ & 总荧 & I-10. Efficiency & 4 & $\begin{array}{l}\text { Decisions in coordination forums such as the DEC were usually made quickly and efficiently. Urgent } \\
\text { decisions such as during drought emergencies were timely. }\end{array}$ \\
\hline 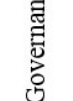 & อั & I-11. Fit & 2 & $\begin{array}{l}\text { Some aspects of decision making were reasonably well adapted to local conditions. Decisions on livestock } \\
\text { access to the forest, for example, were made at a level that seems appropriate. On the whole, however, the } \\
\text { governance system was not able to bring focused attention to matters at a Mt. Marsabit level. }\end{array}$ \\
\hline 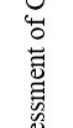 & $\mathrm{I}-12$. & Learning capacity & 2 & $\begin{array}{l}\text { The learning capacity of the governance system was undermined by loss of knowledge that occurred every } \\
\text { time a government staff member was transferred. Trust between community members and key government } \\
\text { actors such as KFS and KWS was minimal. In recent years, however, EMCs have been increasing trust at } \\
\text { community and intercommunity level. }\end{array}$ \\
\hline 嵌 & $\mathrm{I}-13$. & Leadership & 2 & $\begin{array}{l}\text { The governance system did not support the emergence of leadership in the system but neither did it undermine } \\
\text { it. The fact that government officers played a central role in the governance system made the system } \\
\text { vulnerable to staff transfers. }\end{array}$ \\
\hline
\end{tabular}

course of analysis and transcripts coded iteratively according to these additional themes (see Table 4).

\section{STUDY AREA}

Mt. Marsabit is an ecosystem of vital importance for tens of thousands of people in Marsabit County in Kenya. A massive shield volcano covering an area of thousands of square kilometers and reaching to an elevation of 1707 meters, it has a climate very different than the lowlands surrounding it. Whereas in parts of the nearby lowlands annual precipitation can average less than $300 \mathrm{~mm}$, the mountain receives a mean annual rainfall of approximately $800 \mathrm{~mm}$. as well as a significant level of moisture through condensation in the "cloud forest." Through its surface and groundwater runoff, Mt. Marsabit plays a critical role in hydrology far beyond the mountain itself. On the mountain, an area of $1552 \mathrm{~km}^{2}$ is gazetted as a national reserve and within that a smaller area, $157 \mathrm{~km}^{2}$, is also designated as a forest reserve. There have been a web of movements and relationships, wildlife migration, livestock movement, hydrological flows, and various types of resource harvesting by human beings that suggest Mt. Marsabit as a whole constitutes a landscape ecosystem. Wildlife migrations for instance do not stop at the reserve boundaries, and the ecosystem extends beyond reserve boundaries and includes a substantial area of community land (formerly "trust land"), which falls under the management purview of local authorities. These relationships tie together the reserves and the trust land, and the forested areas and the nonforested areas. Relationships beyond the slopes of the mountain to the lowlands, while relevant, are weaker. 
Table 3. Assessment of governance outcomes. $(\mathrm{DEC}=$ District Environment Committee; DSG = District Steering Group).

\begin{tabular}{|c|c|c|}
\hline Questions/Indicators & Score & Explanation \\
\hline Resolving Trade-offs; & 3 & $\begin{array}{l}\text { The economic, environmental, and social trade-offs that are inherent in the decisions being } \\
\text { made were considered. To a certain extent, however, this happened on a decision-by-decision } \\
\text { basis rather than being based on a systematic and transparent process. The poorest and most } \\
\text { vulnerable did not have their interests adequately represented in the resolution of trade-offs. }\end{array}$ \\
\hline $\begin{array}{l}\text { Contributing to just } \\
\text { power relations; }\end{array}$ & 3 & $\begin{array}{l}\text { The governance system, through its technical approach to coordination and information } \\
\text { sharing resulted in community members, especially the poorest, having little voice in decision } \\
\text { making. The distribution of authority across many actors helped to limit the role of coercive } \\
\text { power. On the other hand, the governance system did little to empower the poorest and most } \\
\text { marginalized people. }\end{array}$ \\
\hline Setting Direction; & 2 & $\begin{array}{l}\text { The technical committees for coordination (e.g., DEC, DSG, etc.) helped to establish some } \\
\text { common ground particularly among government departments, but not detailed shared visions } \\
\text { or strategic plans. Collective planning at the landscape ecosystem (Mt. Marsabit) level has been } \\
\text { almost completely absent. }\end{array}$ \\
\hline Building Community; & 2 & $\begin{array}{l}\text { At Location level, environmental management committeess have played some role in bringing } \\
\text { communities together. At a landscape ecosystem (Mt. Marsabit) level, however, opportunities } \\
\text { have been missed and the governance system has done little to build community and shared } \\
\text { identities. }\end{array}$ \\
\hline
\end{tabular}

Table 4. Emergent themes identified in interviews and focus group discussions.

\begin{tabular}{lcc}
\hline \hline Theme & $\begin{array}{c}\text { Number of } \\
\text { Sources Coded } \\
\text { for the Theme }\end{array}$ & $\begin{array}{c}\text { Number of } \\
\text { References to the } \\
\text { Theme }\end{array}$ \\
\hline Firewood/charcoal & 17 & 60 \\
Enforcement & 13 & 26 \\
Boreholes & 8 & 25 \\
Conflict & 12 & 20 \\
Livestock access to & 9 & 19 \\
resources & & \\
\hline
\end{tabular}

Therefore, although "Mt. Marsabit" does not correspond precisely to any particular jurisdiction, treating Mt. Marsabit as a landscape for purposes of this assessment, and perhaps too for purposes of management, is appropriate. Although there has been little in the way of governance mechanisms and procedures consciously designed with the explicit intention to deal with problems and challenges at the level of Mt. Marsabit, the mix of district and national government, traditional, and community governance mechanisms together have constituted what has been, in effect, the governance system for Mt. Marsabit and it was this emergent governance system that was the focus of our study. The first election of devolved county governments under Kenya's 2010 constitution took place in March 2013. Mt. Marsabit is within Marsabit County, which operates as an independent entity from the national government. However, the two levels of government are supposed to consult in management of natural resources. The provisions in the constitution related to devolution are being implemented in steps, and at the time of this research were still at the earliest stages. Our assessment of governance for the Mt. Marsabit landscape ecosystem, therefore, focused on the arrangements that existed prior to the new constitution.

\section{FINDINGS}

Description and assessment of processes and capacities

An inventory that we conducted of forums, organizations, and other decision-making bodies in the governance system is summarized in Appendix 2. This inventory confirmed that there were few decision-making forums, organizations, and institutions within the overall governance system whose mandate and focus correspond to the level of Mt. Marsabit. Some of the key actors had a primary focus at a level smaller than the Mt. Marsabit landscape ecosystem as a whole. Environmental management committees (EMCs), for example, are community-based organizations that work at community and location level ${ }^{[1]}$. In addition, with the two types of protected area designations, the national reserve and the forest reserve, comes the involvement of two different government agencies: the Kenya Forest Service (KFS) and the Kenya Wildlife Service (KWS). Although these two agencies are concerned with forest and wildlife resources generally, they have a primary focus on the gazetted protected areas. Other actors and forums had a focus at a level larger than Mt. Marsabit, specifically at the level of Marsabit District: for example, the County Council and forums such as the District Environment Committee.

In the predevolution governance system, only two entities had a focus corresponding to the Mt. Marsabit level. One of these was a community forest association which, at the time of the research, had gone through some of the formal procedures for its formation, but had not yet become active. The other has been the Marsabit Environmental Conservation Group (MECOG), an organization that exists essentially to implement a single project aimed at promoting protection and regeneration of the Marsabit forest, particularly by providing water points for livestock on the lower slopes of the mountain away from the forest. In short, the governance system was made up of a variety of organizations and forums, almost none of which focused explicitly at the level of Mt. Marsabit (see Fig. 1). 
Fig. 1. Key actors and the level at which they operate. (ALRMP $=$ Arid Lands Resource Management Project; NEMA = National Environment Management Authority; DSG = District Steering Group; DEC = District Environment Committee; MECOG = Marsabit Environmental Conservation Group; KFS = Kenya Forest Service; KWS = Kenya Wildlife Service; EMCs = environmental management committees).

\begin{tabular}{ll}
\hline \multicolumn{1}{c}{ Level } & \multicolumn{1}{c}{ Actor } \\
\hline Marsabit District & $\begin{array}{l}\text { ALRMP, NEMA, District } \\
\text { Commissioner, DSG, DEC, } \\
\text { DSC, County Council }\end{array}$ \\
\hline $\begin{array}{l}\text { Mt. Marsabit } \\
\text { Forest Reserve/ } \\
\text { National Reserve }\end{array}$ & KFS, KWS \\
Location & EMCs \\
\hline Community & \\
\hline
\end{tabular}

Based on analysis of interviews, the focus group discussion, and the multistakeholder workshop, the 17 evaluative indicators from the assessment framework were assessed using the scoring criteria described above. Assessment of the first 13 indicators, pertaining to governance processes and governance capacities is summarized in Table 2.

\section{The role of EMCs in the governance system}

Here, we discuss two particular aspects of the governance system in greater detail: the place and role of EMCs in the system, and the nature of institutional linkages. One category of policy frameworks helping to shape the governance system has been the community-based natural resource management in various sectors. Legislation and regulations in the water sector lay out the procedures and prerogatives of water resource user associations but this process has been very slow in Marsabit. At the time of the research, the formation of a community forest association on Mt. Marsabit was only a bit further along. More important for the Mt. Marsabit governance system have been the EMCs. In the Kenyan context, EMCs are interesting firstly in that, unlike water resource user associations or community forest associations, they are not under the umbrella of a nation-wide program or policy framework, but rather are an experiment unique to Marsabit. They were established in the late 1990s throughout most of Marsabit through the joint efforts of the National Environment Management Authority (NEMA) and the German development agency GTZ, as a part of the Marsabit Integrated Development Program (Haro et al. 2005). Their governmental department parent is NEMA, but other agencies such as KFS collaborate with them.

In analyzing interview and focus group transcripts, emergent themes were coded, the top five of which are shown in Table 4. Of these five, references to EMCs featured prominently in respondents' comments on all of them except for boreholes. Although the EMCs operate at a smaller scale than the Mt. Marsabit landscape, pertaining to administrative units called locations, during the course of the assessment it became clear that they play a pivotal role in natural resource governance on $\mathrm{Mt}$. Marsabit. When the EMCs were being established, a significant investment of time was made in consultation with communities on the structure EMCs were to take and the rules they were to enforce. Whereas it is not uncommon for NGOs working in rural Africa to speak of working with traditional institutions, EMCs are a genuine hybrid between traditional and modern. During the course of this research several different respondents were asked about the connections between EMCs and traditional institutions. The responses offered in one focus group discussion with Rendille elders and EMC members were typical:

Respondent \#1: Yes. The EMC members are even elected from among the naabo [clan council].

Respondent \#2: There is nothing that the EMCs can do without the traditional institutions. They make decisions together. People even know all of the EMC members by name. The decisions are even made by the naabo.

In terms of the 17 criteria used in the assessment, it is perhaps legitimacy where the importance of the EMCs and of their integral connection with traditional institutions is clearest. For legitimacy, the overall governance system was assessed as weak. Throughout the different parts of the system, though, the picture is quite mixed. Responses to questions in key informant interviews and anecdotes and related by our respondents suggest that the authority of mandated bodies such as KFS, KWS, and NEMA is accepted, if not approved of, by community members insofar as they will often go through proper channels with these agencies for access to resources. This kind of respect, however, is a begrudging one: KFS and KWS particularly, and the roles they play, are not looked upon highly by most community members. Traditional institutions, on the other hand, are generally seen as legitimate. The level of respect that EMCs enjoy, in part because of their connections to traditional institutions, is also quite high. For example, one respondent told of an incident that had happened just a few days prior to the interview. A truck from the County Government had traveled part way down the mountain from Marsabit town to an area near one of the other settlements to collect firewood. It was stopped by EMC members. "Imagine!" the respondent said. "This is a lorry with a government logo on the side, from a higher level of the government than the EMC. But they stopped it and said, 'You didn't get permission from us to collect this firewood.'" The anecdote was later confirmed by others.

There is a connection here with another of the criteria: the capacity of the governance system to access and/or generate financial, human, and political resources. Of all 17 criteria, it is here that the governance system was assessed as weakest. A critical manifestation of this relates to limited capacity for enforcement, which was also one of the top emergent themes identified in our analysis (see Table 4$)^{[2]}$. One of the impacts of the shortage of resources was reduced capacity for enforcement. In particular, guard staff for KWS and KFS were judged, by respondents from those two organizations and some other respondents, to be inadequate. This is compensated, although in an incomplete way, by the capacity of the EMCs. As would be expected from a community-based approach, the ways that EMCs engage in enforcement relies on their personal acquaintance with individual 
resource users, their legitimacy in the eyes of community members, and as much through use of social pressure as through more conventional enforcement approaches.

That the EMCs enjoy a high level of legitimacy is not to say that they face no challenges in having their plans and rules respected. EMC members interviewed indicated that livestock owners from other locations, in some cases will respect EMC management of resources, in other cases not. Another issue is the legal mandate for EMCs, which are not directly recognized in any kind of national legislation or regulations. Instead, EMCs were officially an extension of the District Environment Committee and were acting on behalf of NEMA. Some respondents suggested that this limited form of official legitimization of EMCs may also be playing a role in preventing EMCs from being seen by community members as fully legitimate.

In regards to accountability, EMCs are structured with regular meetings of their members, and an annual general meeting every two years with election of members. The bylaws used by EMCs were determined through a participatory, public process for each EMC. Generally, community members are welcome to request time in EMC meetings to present issues and ask questions. Although different EMCs may vary in regard to how scrupulously they follow these procedures, generally the EMCs have a reasonable level of accountability to the general public.

Several respondents highlighted the importance of EMCs to the responsiveness of the governance system. At a very local level, this responsiveness can be seen in the way in which EMCs are able to consider individual circumstances. One respondent gave the example of a family facing some crisis, such as having had their house burn down, coming to the EMC to seek extraordinary permission to collect firewood to sell. As another respondent explained, with the EMCs there is responsiveness, but "Before the EMCs, nothing."

\section{Institutional linkages and coordination}

From our analysis of the research findings we conclude that the way in which coordination was done and the nature of institutional linkages had important consequences for the governance system as a whole. The primary mechanisms for coordination and sharing of information in the governance system were district level committees such as the District Steering Group, the District Environment Committee, and District Security Committee made up of government officers from various agencies and departments. These forums emphasized information sharing and harmonization across government departments and agencies. Depending on the particular committee, community representatives and NGOs might also be included. This approach had its strengths. Respondents familiar with these forums agreed that they were very effective at sharing information and achieving coordination amongst government departments, and between government departments and NGOs. The system as a whole was also efficient, with decisions being made, according to our respondents, in a timely and cost-effective way. This is reflected in the assessment scores, with efficiency receiving the highest score of any of the criteria. In the assessment, the governance system also received a strong score of " 3 " for institutional linkages (Indicator no. I-3), based on the scoring criteria.

Nevertheless, the assessment identified some significant problems in this area. The system had at its center what could be called a "technical approach" to planning and coordination. As depicted in Fig. 2, community and customary organizations were not well connected to these forums. Based on questions to our respondents about how closely different actors worked together, which ones participate in which forums, and how information flows among them, we made a judgment as to the relative strength of the linkages among these governance actors and forums. The connection of the county-level thematic forums to community representatives and other community actors was weak. For instance elected representatives, e.g., ward councillors, were not well connected to the forums, tending not to attend and seldom being well informed about them. NGOs provided some connections to community-level actors but this was on an ad hoc, project-by-project basis. The District Environment Committee included a representative of EMCs. However, having a single person to represent all EMCs on the committee, to bring information and views from them and take information and decisions back to them, was insufficient. A small handful of representatives or often a single representative, sitting on these committees, with no resources, cannot be expected to be effective liaisons to the multiplicity of community organizations and stakeholders. EMC members we interviewed knew little or nothing about these committees. Moreover, traditional institutions have depended on their integral connection with the EMCs for their main linkage to the governance system, but given EMCs' otherwise weak connections, the traditional institutions

Fig. 2. Key institutional linkages in the governance system. $(\mathrm{OoP}=$ Office of the President; ALRMP $=$ Arid Lands Resource Management Project; KFS = Kenya Forest Service; KWS = Kenya Wildlife Service; NEMA = National Environment Management Authority; DSC = District Security Committee DSG $=$ District Steering Group; DEC $=$ District Environment Committee; EMCs = environmental management committees; MECOG = Marsabit Environmental Conservation Group).

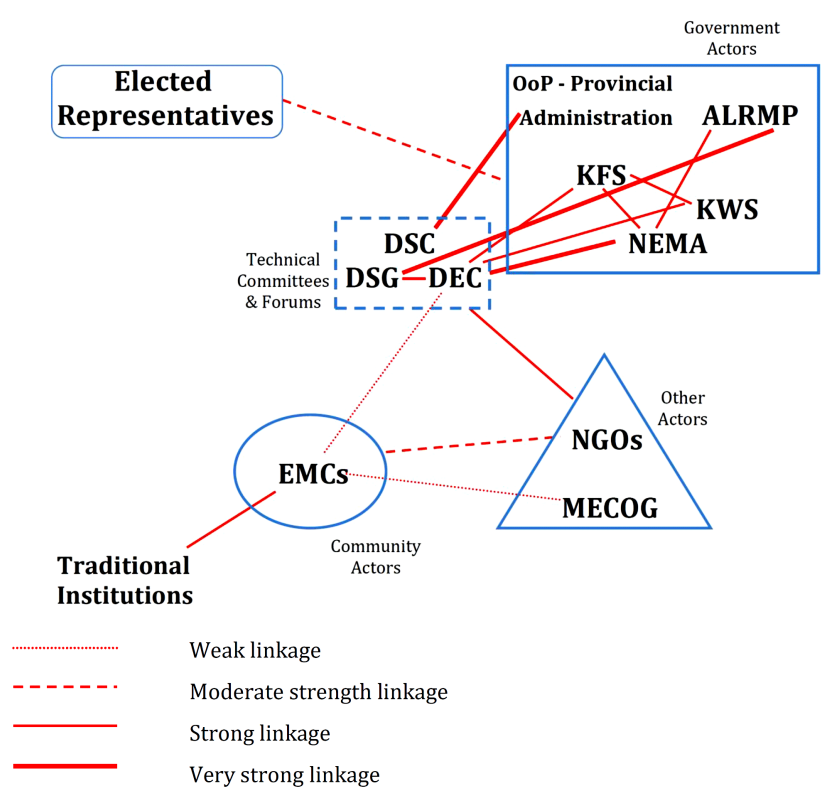


were further marginalized from the main forums for coordination and landscape-level decision making. In applying the scoring criteria for this indicator, it was realized that the criteria place insufficient emphasis on equity and inclusivity in the linkages and on how well linkages connect the full array of institutions, governance actors, and other important stakeholders within the governance system. It is anticipated that the scoring criteria for this indicator will be revised in the next draft of the assessment framework.

\section{Assessment of governance outcome indicators}

The four categories of governance outcomes in the assessment framework are the way in which the governance system resolves trade-offs, contributes to just power relations, sets direction, and builds community. The assessment of these indicators for the Mt. Marsabit governance system is presented in Table 3. For resolving trade-offs, there was disagreement among stakeholders as to whether environmental protection was given too much weight or not enough. However, our respondents in interviews and in discussions in the multistakeholder workshop that we held gave examples of ways that, in decision making, various types of tradeoffs and the need for balance were considered. This was due partly to political perspectives being brought into the otherwise mostly technical format of district-level coordination mechanisms, for instance by the District Commissioner through the District Security Committee. The District Security Committee, chaired by the District Commissioner, played a pivotal role in determining whether and when pastoralists would be allowed to enter the forest with their herds. They were given access but it was not unfettered access: decision making about this access included consideration both of the need for environmental protection and the need for maintaining pastoral livelihoods in drought situations. However, in none of our discussions with respondents about ways in which trade-offs were resolved was there any suggestion that some kind of systematic and transparent process was applied; rather, any balancing among competing objectives and interests seems to have happened on a decision-by-decision and case-by-case basis. One group whose needs were not adequately addressed in the resolution of trade-offs was the poorest segment of the population with resource-dependent livelihoods: e.g., firewood collectors and charcoal producers.

In regards to the ways in which the governance system shaped how power was constituted and used, it is important to note that the system, through its technical approach to coordination in which cross-sectoral coordination and sharing of information happened primarily within technical committees such as the District Environment Committee, community members, especially the poorest and most vulnerable, did not have a direct voice. The distribution of authority across a number of actors did help to limit the ability of any one powerful actor to influence decisions, but there was little in the governance system that can be said to have been empowering poor and vulnerable segments of the population.

The direction setting and community building functions of the governance system were weaker. Some degree of forward looking planning was happening at the location level through the EMCs. At a landscape ecosystem level, the direction setting function was much weaker. Several respondents commented on the lack of visionary leaders. The loss of continuity that happens when key government officers are transferred and how this has affected the development and pursuit of any long term vision was also highlighted. However, the technical coordination committees that existed have at least helped to establish some common ground among those who participate, if not detailed visions or strategic plans.

As for building community, the venues in which people were brought together did create some few opportunities for dialogue. However, the extent to which this happened was restricted by limited resources. Perhaps one of the elements of the governance system that helped to bring different groups and communities together has been the EMCs, particularly in locations that are not made up predominantly of a single ethnic group. Jaldesa EMC, for example, brings together Gabra and Borana communities. On a larger scale, however, an opportunity has been missed in that different EMCs have not been brought together as had been hoped would happen with the creation of the Community Forest Association.

\section{DISCUSSION AND CONCLUSIONS}

In the emergent governance system that corresponds to the Mt. Marsabit landscape, the most important spaces in the governance system where coordination and joint planning took place were the district-level coordination committees such as the District Environment Committee and District Steering Group. These committees were in many ways at the center of the governance system, as suggested by the roles they played in linking different actors. However, as noted above, communities and voices from the grassroots were not well represented in these forums and were connected to them mostly indirectly such as through NGOs. Consideration of the overall governance system in terms of the dimensions used in our assessment framework helps to highlight some of the implications of this situation. The strength of these various dimensions of governance varied among the different organizations and institutions within the governance system, such that those parts of the system for which legitimacy and accountability were strongest were the parts where ability to generate resources was weakest, while the parts of the governance system that had the best access to resources, such as NGOs, standalone projects such as the one being implemented by MECOG, and government departments, was where accountability was weakest or the most indirect.

What is critically important for the Mt. Marsabit governance system is that the institutional linkages in the system did little to reverse this discrepancy. Although linkages were strong amongst government departments through the district-level committees, actors such as clan councils, EMCs, and elected ward councilors were only very weakly connected to the key coordinating bodies and to the parts of the governance system having the strongest ability to mobilize resources (see Fig. 2). As mentioned above, EMCs are integrally connected to traditional institutions and this has been a key aspect of the EMCs' effectiveness at the local level. On the other hand, the weakness of linkages to key formal sector agencies and to district-level coordination and decision-making processes both limited the capacity of the EMCs, and represented an unrealized potential for the governance system as a whole. These factors, together with very prominent place in that system of staff of government departments, which sometimes resulted in loss of continuity owing to staff turnover, suggest an 
explanation for the aspects of governance that scored poorly in our assessment: social learning, the promotion of local leadership, mobilization of resources, and the direction setting function of governance all suffered. Ultimately, the ability of the governance system to initiate and implement concerted action toward management of the ecosystem was wholly inadequate.

Situations in which governments will be willing to address spatial misfit (Galaz et al. 2008) by implementing major readjustments of authority and jurisdiction boundaries to align them with meaningful social-ecological landscapes, as advocated for example in bioregionalism (Sale 2000), are likely to be exceedingly rare. Instead, the management of ecosystems and the resolution of social-ecological trade-offs typically must take place in governance environments in which the authority for key decisions is distributed across jurisdictions and sectors. Even where processes or structures have been explicitly created to cut across sectors at a landscape scale and have a strong mandate for coordination or even regulation, some critically important decisions will be in the hands of other structures and processes that operate according to different scales. Although past research has recognized that landscape governance is "messy" (Kozar et al. 2014), our analysis of this case study goes further: it highlights that governance of landscapes, whether accidental or by design, is carried out not by discrete organizations or institutions but by governance systems. Landscape approaches, of necessity, must aim at collaboration and coordination.

Governance systems are made up of organizations and institutions and linkages amongst them. Environmental governance literature has explored institutional interplay and its role in governance systems in some depth (e.g., Gunderson et al. 2006, Kofinas 2009). Interplay between any two particular institutions is of course relevant, but a governance system is made up of the entire network of institutional linkages in the system. These linkages help to determine the characteristics of the governance system including the quality of governance processes (described according to criteria such as deliberation, the ability to generate resources, accountability and legitimacy), the strength of governance capacities (capacities for learning, for effective decision making, and for the promotion of leadership), and ways in which governance social functions are carried out (the ways in which the system resolves trade-offs, shapes how power is used, sets direction, and builds community). What the Mt. Marsabit case study shows is that the strengths and weaknesses of different dimensions of governance among the various components of the system do not simply average out to represent the strengths and weaknesses of the governance system. Within any governance system, particular institutions and organizations will have differing strengths and weaknesses in terms of these kinds of criteria. The weakness of institutional linkages in certain parts of a governance system, however, may result in the positive attributes of particular components never becoming attributes of the governance system as a whole, as was the case for Mt. Marsabit where the strengths of the EMCs in terms of legitimacy and responsiveness never translated to the landscape governance system as a whole. We postulate, conversely, that appropriate linkages that support the flow of resources and information, and that connect different actors to decisions being made in different parts of the system also serve to create connections among key dimensions of effective governance within the system, dimensions such as use of knowledge, capacity to generate resources, fit, learning, legitimacy, accountability, and responsiveness.

Devolution in Kenya, as structures are created and revised in the process of creating the framework needed under the 2010 constitution, offers great potential for steering governance systems for natural resources management toward greater effectiveness. In the forestry sector, for instance, new legislation, the Forest Conservation and Management Act, will now require regulations. The new legislation and regulations in various areas will need to recognize the importance of community-based governance and provide the institutional linkages that can enable enforcement by community organizations and promoting linkages with county government. County assemblies, for their part, can legitimize community-based resource management through their own legislation. In Marsabit, EMCs should be mainstreamed in the county structures. The constitution further aims at addressing inequity in natural resource sharing. Article 69 (1) and (2) clearly spells out that the people of Kenya should benefit equitably from the sustainable exploitation, utilization, and management of natural resources and at the same time, work to conserve and protect these resources (Republic of Kenya 2010). The constitution expects that costs and benefits in managing natural resources should be shared among the national and county government, resources managers, and the citizens. In order to achieve this, as counties create updated versions the former district coordination committees and create new entities such as county forest conservation committees, attention should be given to ensuring that strong linkages are established amongst all key stakeholders, including communities and their representatives, and not simply replicate the technical approach to coordination that was prominent in the past.

The implications apply not only to Kenya and are relevant not only for landscape approaches and ecosystem management, but also for efforts focused on community-based approaches to conservation and natural resource management at smaller scales. Local level commons are embedded in a multilevel world (Berkes 2009). To be effective, community-based approaches cannot focus only at the level of local commons any more than landscape approaches can focus only at the landscape level. Landscape approaches and initiatives aimed at ecosystem-based management, moreover, should build on strengths including the strengths of community-level organizations and institutions, such as the EMCs in Marsabit. The way to build on these strengths is to work toward effective landscape-level governance systems by establishing appropriate institutional linkages. These can include forums for coordination and information sharing, and processes for developing shared visions, for planning, and for monitoring. Of the various linkages that characterize a governance system, those that might have given community level actors a meaningful voice at higher levels and in spaces where key decisions are being made were found to be weak the Mt. Marsabit governance system, a situation that we argue helps to explain some of the weaknesses in other dimensions of governance there. Institutional linkages that help to provide a voice and connect community level actors to spaces of decision making are perhaps the most critical for enabling effective landscape governance systems. 


\begin{abstract}
${ }^{[1]}$ Prior to the 2010 Constitution, administrative levels in Kenya included sublocation, location, division, district, and province. Sublocations typically were made up of a small number of villages or hamlets, sometimes only one. Locations typically included two or three sublocations.

${ }^{[2]}$ Capacity for enforcement of rules would seem to be a product of various of the governance process indicators such as legitimacy and ability to generate resources but is not itself explicitly identified as one of the criteria in the assessment framework. It may be added in the next draft of the framework.
\end{abstract}

Responses to this article can be read online at: http://www.ecologyandsociety.org/issues/responses. php/9933

\section{Acknowledgments:}

The research described here was funded the Social Sciences and Humanities Research Council of Canada (SSHRC), the CGIAR Research Program on Dryland Systems led by the International Center for Agricultural Research in the Dry Areas (ICARDA) and the CGIAR Research Program on Livestock led by ILRI.

\section{LITERATURE CITED}

Andersson, K. P., and E. Ostrom. 2008. Analyzing decentralized resource regimes from a polycentric perspective. Policy Sciences 41(1):71-93. http://dx.doi.org/10.1007/s11077-007-9055-6

Berkes, F. 2002. Cross-scale institutional linkages: perspectives from the bottom up. Pages 293-321 in E. Ostrom, T. Dietz, N. Dolšak, P. C. Stern, S. Stonich, and E. U. Weber, editors. The drama of the commons. National Academy Press, Washington, D. C., USA.

Berkes, F. 2009. Revising the commons paradigm. Journal of Natural Resources Policy Research 1(3):261-264. http://dx.doi. org/10.1080/19390450903040454

Berkes, F., and C. Folke. 2002. Back to the future: ecosystem dynamics and local knowledge. Pages 121-146 in L. H. Gunderson and C. S. Holling, editors. Panarchy: understanding transformations in human and natural systems. Island Press, Washington, D.C., USA.

Biermann, F. 2008. Earth system governance: a research agenda. Pages 277-301 in O. R. Young, L. A. King, and H. Schroeder, editors. Institutions and environmental change: principal findings, applications, and research frontiers. MIT Press, Cambridge, Massachusetts, USA. http://dx.doi.org/10.7551/mitpress/9780262240574.003.0009

Biermann, F., M. M. Betsill, J. Gupta, N. Kanie, L. Lebel, D. Liverman, H. Schroeder, and B. Siebenhüner. 2009. Earth system governance: people, places, and the planet. Science and implementation plan of the Earth System Governance project. Earth System Governance Report 1, IHDP Report 20. Earth System Governance project, Bonn, Germany.
Brunckhorst, D. J. 2010. Landscapes shaped by people and place institutions require a new conservation agenda. BioScience 60 (8):569-570. http://dx.doi.org/10.1525/bio.2010.60.8.2

Carlsson, L., and F. Berkes. 2005. Co-management: concepts and methodological implications. Journal of Environmental Management 75(1):65-76. http://dx.doi.org/10.1016/j.jenvman.2004.11.008

Cash, D. W., W. N. Adger, F. Berkes, P. Garden, L. Lebel, P. Olsson, L. Pritchard, and O. R. Young. 2006. Scale and cross-scale dynamics: governance and information in a multilevel world. Ecology and Society 11(2):8. http://dx.doi.org/10.5751/ES-01759-110208

Duguma, L. A., P. A. Minang, M. Mpanda, A. Kimaro, and D. Alemagi. 2015. Landscape restoration from a social-ecological system perspective? Pages 63-73 in P. A. Minang, M. van Noordwijk, O. E. Freeman, C. Mbow, J. de Leeuw, and D. Catacutan, editors. Climate-smart landscapes: multifunctionality in practice. World Agroforestry Centre (ICRAF), Nairobi, Kenya.

Duit, A., V. Galaz, K. Eckerberg, and J. Ebbesson. 2010. Governance, complexity, and resilience. Global Environmental Change 20(3):363-368. http://dx.doi.org/10.1016/j.gloenvcha.2010.04.006

Folke, C., T. Hahn, P. Olsson, and J. Norberg. 2005. Adaptive governance of social-ecological systems. Annual Review of Environment and Resources 30:441-473. http://dx.doi.org/10.1146/ annurev.energy.30.050504.144511

Galaz, V., P. Olsson, T. Hahn, C. Folke, and U. Svedin. 2008. The problem of fit among biophysical systems, environmental and resource regimes, and broader governance systems: insights and emerging challenges. Pages 147-186 in O. R. Young, L. A. King, and $\mathrm{H}$. Schroeder, editors. Institutions and environmental change: principal findings, applications, and research frontiers. MIT Press, Cambridge, Massachusetts, USA. http://dx.doi.org/10.7551/ mitpress/9780262240574.003.0005

Gehring, T., and S. Oberthür. 2008. Interplay: exploring institutional interaction. Pages 187-224 in O. R. Young, L. A. King, and H. Schroeder, editors. Institutions and environmental change: principalfindings, applications, and research frontiers. MIT Press, Cambridge, Massachusetts, USA. http://dx.doi.org/10.7551/ mitpress/9780262240574.003.0006

Gehring, T., and E. Ruffing. 2008. When arguments prevail over power: the CITES procedure for the listing of endangered species. Global Environmental Politics 8(2):123-148. http://dx.doi. org/10.1162/glep.2008.8.2.123

Graham, J., B. Amos, and T. Plumptre. 2003. Governance principles for protected areas in the 21 st century. Report prepared for the Fifth World Parks Congress, Durban, South Africa. Institute on Governance, Ottawa, Ontario, Canada. [online] URL: https:// www.files.ethz.ch/isn/122197/pa governance2.pdf

Gunderson, L. H., S. R. Carpenter, C. Folke, P. Olsson, and G. Peterson. 2006. Water RATs (resilience, adaptability, and transformability) in lake and wetland social-ecological systems. Ecology and Society 11(1):16. http://dx.doi.org/10.5751/ ES-01556-110116

Gupta, J., C. Termeer, J. Klostermann, S. Meijerink, M. van den Brink, P. Jong, S. Nooteboom, and E. Bergsma. 2010. The 
adaptive capacity wheel: a method to assess the inherent characteristics of institutions to enable the adaptive capacity of society. Environmental Science \& Policy 13(6):459-471. http://dx. doi.org/10.1016/j.envsci.2010.05.006

Haro, G. O., G. J. Doyo, and J. G. McPeak. 2005. Linkages between community, environmental, and conflict management: experiences from northern Kenya. World Development 33 (2):285-299. http://dx.doi.org/10.1016/j.worlddev.2004.07.014

Imperial, M. T. 1999. Institutional analysis and ecosystem-based management: the institutional analysis and development framework. Environmental Management 24(4):449-465. http://dx. doi.org/10.1007/s002679900246

Jentoft, S., T. C. van Son, and M. Bjørkan. 2007. Marine protected areas: a governance system analysis. Human Ecology 35 (5):611-622. http://dx.doi.org/10.1007/s10745-007-9125-6

Kofinas, G. P. 2009. Adaptive co-management in social-ecological governance. Pages 77-101 in F. S. Chapin III, G. P. Kofinas, and C. Folke, editors. Principles of ecosystem stewardship: resiliencebased natural resource management in a changing world. Springer, New York, New York, USA. http://dx.doi.org/10.1007/978-0-387-73033-2 4

Kozar, R., L. E. Buck, E. G. Barrow, T. C. H. Sunderland, D. E. Catacutan, C. Planicka, A. K. Hart, and L. Willemen. 2014. Toward viable landscape governance systems: what works? EcoAgriculture Partners, on behalf of the Landscapes for People, Food, and Nature Initiative, Washington, D.C., USA.

Lebel, L., J. M. Anderies, B. Campbell, C. Folke, S. HatfieldDodds, T. P. Hughes, and J. Wilson. 2006. Governance and the capacity to manage resilience in regional social-ecological systems. Ecology and Society 11(1):19. http://dx.doi.org/10.5751/ ES-01606-110119

Lockwood, M. 2005. Integration of natural area values: conceptual foundations and methodological approaches. Australian Journal of Environmental Management 12 (Supplementary Issue):8-19. http://dx.doi.org/10.1080/1448656$\underline{3.2005 .10648659}$

Lockwood, M. 2010. Good governance for terrestrial protected areas: a framework, principles and performance outcomes. Journal of Environmental Management 91(3):754-766. http://dx. doi.org/10.1016/j.jenvman.2009.10.005

Mbow, C., C. Neely, and P. Dobie. 2015. How can an integrated landscape approach contribute to the implementation of the Sustainable Development Goals (SDGs) and advance climatesmart objectives? Pages 103-116 in P. A. Minang, M. van Noordwijk, O. E. Freeman, C. Mbow, J. de Leeuw, and D. Catacutan, editors. Climate-smart landscapes: multifunctionality in practice. World Agroforestry Centre (ICRAF), Nairobi, Kenya.

Miller, D. 1992. Deliberative democracy and social choice. Political Studies 40(Special Issue, Prospects for Democracy):54-67.

Minang, P. A., L. A. Duguma, D. Alemagi, and M. van Noordwijk. 2015b. Scale considerations in landscape approaches. Pages 121-133 in P. A. Minang, M. van Noordwijk, O. E. Freeman, C. Mbow, J. de Leeuw, and D. Catacutan, editors. Climate-smart landscapes: multifunctionality in practice. World Agroforestry Centre (ICRAF), Nairobi, Kenya.

Minang, P. A., M. van Noordwijk, O. E. Freeman, C. Mbow, J. de Leeuw, and D. Catacutan, editors. 2015a. Climate-smart landscapes: multifunctionality in practice. World Agroforestry Centre (ICRAF), Nairobi, Kenya.

Olsson, P. 2007. The role of vision in framing adaptive comanagement processes: lessons from Kristianstads Vattenrike, southern Sweden. Pages 268-285 in D. Armitage, F. Berkes, and N. Doubleday, editors. Adaptive co-management: collaboration, learning and multi-level governance. University of British Columbia Press, Vancouver, British Columbia, Canada.

Pahl-Wostl, C. 2009. A conceptual framework for analysing adaptive capacity and multi-level learning processes in resource governance regimes. Global Environmental Change 19(3):354-365. http://dx.doi.org/10.1016/j.gloenvcha.2009.06.001

Powell, R. B. 2010. Developing institutions to overcome governance barriers to ecoregional conservation. Pages 53-66 in S. C. Trombulak and R. F. Baldwin, editors. Landscape-scale conservation planning. Springer, Dordrecht, The Netherlands. http://dx.doi.org/10.1007/978-90-481-9575-6 4

Republic of Kenya. 2010. The Constitution of Kenya. Republic of Kenya, Nairobi, Kenya.

Robinson, L. W., N. Bennett, L. A. King, and G. Murray. $2012 b$. "We want our children to grow up to see these animals": values and protected areas governance in Canada, Ghana and Tanzania. Human Ecology 40:571-581. http://dx.doi.org/10.1007/s10745-012-9502-7

Robinson, L. W., and F. Berkes. 2011. Multi-level participation for building adaptive capacity: formal agency-community interactions in northern Kenya. Global Environmental Change 21 (4):1185-1194. http://dx.doi.org/10.1016/j.gloenvcha.2011.07.012

Robinson, L. W., P. Dearden, and A. Orozco. 2012a. Framework for assessing governance for landscape-level ecosystem-based management. Draft 2.1. Vancouver Island University, Nanaimo, British Columbia, Canada. [online] URL: http://www.viu.ca/ landscapelevel/files/2012/09/LandscapeLevelGovernanceAssessmentFramework.d2.1.pdf

Robinson, L. W., and E. Makupa. 2015. Using analysis of governance to unpack community-based conservation: a case study from Tanzania. Environmental Management 56 (5):1214-1227. http://dx.doi.org/10.1007/s00267-015-0573-2

Rowlands, J. 1997. Questioning empowerment: working with women in Honduras. Oxfam, Oxford, UK. http://dx.doi. org/10.3362/9780855988364

Sale, K. 2000. Dwellers in the land: the bioregional vision. University of Georgia Press, Athens, Georgia, USA.

Sayer, J. A., T. Sunderland, J. Ghazoul, J.-L. Pfund, D. Sheil, E. Meijaard, M. Venter, A. K. Boedhihartono, M. Day, C. Garcia, C. van Oosten, and L. E. Buck. 2013. Ten principles for a landscape approach to reconciling agriculture, conservation, and other competing land uses. Proceedings of the National Academy of Sciences 110(21):8349-8356. http://dx.doi.org/10.1073/ pnas. 1210595110 
Slocombe, D. S. 1998. Lessons from experience with ecosystembased management. Landscape and Urban Planning 40 (1-3):31-39. http://dx.doi.org/10.1016/S0169-2046(97)00096-0

Smith, D. R., A. Gordon, K. Meadows, and K. Zwick. 2001. Livelihood diversification in Uganda: patterns and determinants of change across two rural districts. Food Policy 26(4):421-435. http://dx.doi.org/10.1016/S0306-9192(01)00012-4

Smith, G. 2003. Deliberative democracy and the environment. Routledge, London, UK. http://dx.doi.org/10.4324/9780203207994

Waltner-Toews, D., and J. Kay. 2005. The evolution of an ecosystem approach: the diamond schematic and an adaptive methodology for ecosystem sustainability and health. Ecology and Society 10(1):38. http://dx.doi.org/10.5751/ES-01214-100138

Wyborn, C. 2015. Co-productive governance: a relational framework for adaptive governance. Global Environmental Change 30:56-67. http://dx.doi.org/10.1016/j.gloenvcha.2014.10.009

Young, O. R. 1996. The effectiveness of international governance systems. Pages 1-46 in O. R. Young, G. J. Demko, and K. Ramakrishna, editors. Global environmental change and international governance. University Press of New England, Lebanon, New Hampshire, USA.

Young, O. R. 2002. The institutional dimensions of environmental change: fit, interplay and scale. MIT Press, Cambridge, Massachusetts, USA.

Young, O. R. 2008. Institutions and environmental change: the scientific legacy of a decade of IDGEC research. Pages 3-45 in O. R. Young, L. A. King, and H. Schroeder, editors. Institutions and environmental change: principal findings, applications, and research frontiers. MIT Press, Cambridge, Massachusetts, USA. http://dx.doi.org/10.7551/mitpress/9780262240574.003.0001

Young, O. R. 2010. Institutional dynamics: resilience, vulnerability and adaptation in environmental and resource regimes. Global Environmental Change 20(3):378-385. http://dx. doi.org/10.1016/j.gloenvcha.2009.10.001 
Appendix 1. Key informant interview respondents.

\begin{tabular}{|c|c|}
\hline $\begin{array}{l}\text { Staff of nongovernmental/community-based } \\
\text { organizations }\end{array}$ & 3 \\
\hline Government staff & 10 \\
\hline $\begin{array}{l}\text { Community representatives, leaders of } \\
\text { community-based organizations, and elders }\end{array}$ & 8 \\
\hline $\begin{array}{l}\text { Current and former local political } \\
\text { representatives }\end{array}$ & 2 \\
\hline Total & 23 \\
\hline
\end{tabular}


Appendix 2. Key governance actors and forums.

GOVERNMENT ACTORS ${ }^{\dagger}$

- Kenya Forest Service (KFS)

- Kenya Wildlife Service (KWS)

- Arid Lands Resource Management Project (ALRMP)

- National Environment Management Authority (NEMA)

- The Provincial Administration, including the District Commissioner and Chiefs

\section{TECHNICAL COMMITTEES AND FORUMS}

- The District Steering Group (DSG)

- The District Environment Committee (DEC)

- The District Security Committee (DSC)

TRADTIONAL AND COMMUNITY ACTORS

- Traditional institutions (elders, clan councils such as the Rendille Naabo and Gabra Yaa)

- Environmental Management Committees (EMCs)

ELECTED REPRESENTATIVES

- Ward councilors

CIVIL SOCIETY

- Nongovernmental Organizations (NGOs)

- Marsabit Environmental Conservation Group (MECOG)

\footnotetext{
$\dagger$ This is not meant to be a comprehensive list of relevant stakeholders. Rather it lists the actors and forums most directly relevant to environmental management and protection at the level of the Mt. Marsabit landscape ecosystem.
} 